\title{
Study on the Curriculum Design of Preschool Education Major in Private Colleges in Shaanxi Province from the Perspective of Professionalism
}

\author{
Taking the Preschool Education Major in X University as an Example*
}

\author{
Yabo Yang \\ Xi'an Fanyi University \\ Xi'an, China
}

\begin{abstract}
As the country and society require preschool education talents to be more and more professional, a large number of high-quality and professional talents have been needed by the preschool education market. This article studies the current situation of curriculum setting in $X$ university from the perspective of professionalism, analyzes the training objectives, specifications and requirements, curriculum structure, curriculum content and curriculum implementation, and builds a curriculum system that is suitable for cultivating applicationoriented technical personnel.
\end{abstract}

Keywords—professionalism; preschool education; curriculum setting

\section{INTRODUCTION}

There is a growing demand for high-quality, professional preschool education teachers in the current preschool education market. The state elaborates the professional standards of kindergarten teachers in various policies and regulations on preschool education. This raises higher requirements for the training of preschool education professionals in colleges. Colleges need to embody professional skills in curriculum setting, improve the curriculum system, and cultivate high-quality preschool teachers with professional knowledge and skills.

In recent years, preschool education has been highly valued and supported by the national government. The state has formulated a series of policies and regulations to promote the development of preschool education. "The Outline of National Medium and Long Term Education Reform and Development Plan (2010-2020)"(abbreviated as "Education Plan Outline") clearly puts forward the strategic goal of basically popularizing pre-school education by 2020. To achieve this strategic goal, it is necessary for the government to increase financial investment in pre-school education, expand the resource allocation of pre-school education in multiple ways, increase pre-school education institutions to receive the pre-school children born due to the second-child policy, and establish a large number of qualified kindergartens. Then a lot of

*Project Source: Xi'an Fanyi University's 2017 pre-school education teaching team construction, project number ZT1706. preschool education talents will be needed. With the advancement of the society and the improvement of parents' education literacy, kindergartens are in urgent need of preschool teachers with professional skills and qualities. Many preschool education experts have clearly pointed out that strengthening the construction of the teaching teams is the key link, main approach and prerequisite guarantee for improving the quality of preschool education. Therefore, colleges and universities have the responsibility of cultivating outstanding preschool education professionals. As a senior teacher working at a private college in Shaanxi, I deeply understand that professional education is an important way to cultivate preschool education talents. Cultivating applied pre-school education talents conforms to the current development trend of Chinese education.

\section{CURRENT SITUATION OF CURRICULUM SETTINGS OF PRESCHOOL EDUCATION MAJOR IN X UNIVERSITY}

\section{A. Introduction to Preschool Education Major in X University}

Founded in 1987, X University was approved as a university for undergraduates in 2005. In 2009, it obtained the right to confer a bachelor's degree. In 2013, it passed the undergraduate teaching assessment. In 2014, it was identified as one of the first pilot schools for applied transformation. In 2016, it was approved as the pilot school of "management, schooling and assessment" in Shaanxi Province. In 2018, it was evaluated by Shaanxi Provincial Department of Education as a first-rate college construction unit in Shaanxi Province. In 2007, the Department of Education of Shaanxi Province approved the English Language Education Major of the School of Foreign Languages in X University as a provincial key major. From August 2012, the university began to enroll preschool education students in English major. From August 2013, the university began to recruit vocational pre-school education students to further accumulate schooling experience. In 2015, the university began to enroll undergraduate students in preschool education major. Through full investigation and exchanges among schools, the university constantly revised and improved the professional personnel training plan, paid attention to the reform of teaching content and curriculum 
system, established teaching teams and practical training bases, and focused on cultivating high-quality skilled talents. These have laid a good foundation for running the school.

\section{B. Training Objectives, Training Specifications and Requirements of the Preschool Education Major in X University}

1) Training objectives: The pre-school education major of $\mathrm{X}$ university cultivates high-quality and application-oriented specialists with good ideological qualities, cultural qualities and scientific literacy, noble professional spirit, strong sense of social responsibility, good learning ability, practical ability and innovative awareness, and professional knowledge. The students are supposed to have the basic skills of painting, playing, dancing, singing and bilingual teaching, develop themselves in morality, intelligence, sports, and art to meet the needs of regional economic and social development. After graduation, they can work in kindergartens and other preschool education institutions in teaching, management, service, etc.

\section{2) Training specifications and requirements}

a) Knowledge structure: Master the basic knowledge and theory of caring for and educating preschool child; master basic knowledge of preschool children's bilingual education; master relevant knowledge of kindergarten management and early childhood education; be familiar with national and local guidelines, policies and regulations on preschool education; know the frontier theory, reform and development trend in preschool education at home and abroad.

b) Capability structure: Have strong communication, teamwork, and innovation capabilities; Have the ability to implement childcare and education based on the child's physical and mental development and age; have the skills of singing, playing piano, dancing, painting, making teaching aids, creating kindergarten environment, and storytelling; have the comprehensive art teaching ability to perform painting, playing, jumping and singing for children; have the ability to design and organize bilingual teaching activities and skillfully use modern teaching facilities; have the ability to organize and manage kindergarten classes, organize and guide activities for 0-3 years old children.

c) Quality structure: Students should love the socialist motherland, support the leadership of the Communist Party of China, firmly establish and consciously practice the core values of socialism, establish scientific world, life and value outlook, have a high level of humanities and science literacy, good physical fitness, psychological quality, and sound personality; establish scientific view on children, education and development, have noble morality, have the ability to serve as a teacher; have the professional qualities of lawabiding, pioneering and enterprising, dedicating and innovating; have a certain degree of artistic accomplishment and healthy aesthetic.

Through the above introduction of the $\mathrm{X}$ university preschool education major's training objectives, training specifications and requirements, we can see that the university attaches importance to cultivating the pre-school education students' moral qualities and professional ability, requiring students to have pre-school education professional knowledge and the basic skills of speaking, painting, playing, jumping, singing and bilingual teaching, and attaching importance to improving students' bilingual teaching ability, training preschool education personnel based on the need of regional economic and social development, requiring students to be able to work in teaching, management, service, etc. in kindergartens and other preschool education institutions. In terms of knowledge, ability and quality, students are required to achieve the professionalization level, have professional skills in music, dance, and fine arts, and have the ability to organize various educational and teaching activities in kindergartens. Students should also have basic organization and management skills for kindergarten classes and organizational and instructional skills for 0-3 early childhood education activities. It can be seen that $\mathrm{X}$ University pays attention to the improvement of students' professional accomplishment in the preschool education major in terms of training objectives, training specifications and requirements.

\section{Status Quo of Curriculum Settings of Preschool Education Major in X University}

1) Course structure: The pre-school education major of the $\mathrm{X}$ university has set up general education courses, professional basic courses, professional core courses, professional limited selection courses and professional optional courses, and there is concentrated practice teaching (professional apprenticeships and internships).

2) Course content: The major courses include preschool hygiene (including human anatomy physiology), preschool psychology (including general psychology), preschool education (including pedagogy), preschool education research methods, vocal music, piano, dance, fine arts, preschool professional English, preschool children's health education, etc. The professional limited selection courses are divided into two modules: the management module and the early education module, which provides more choices for the professional development of students. Professional optional courses include bilingual development courses, art skills development courses, professional theory development courses, pre-school teaching skills development courses and children and adolescents social work development courses, covering all aspects of current pre-school education professional skills. Students can freely choose the development courses according to their abilities and interests, improve their professionalism, and increase their future employment opportunities.

3) Course implementation: In terms of curriculum implementation, each course is divided into theoretical time and practical time. Based on the nature of the course, the theory and practice hours are rationally allocated according to the society's needs for preschool education personnel. Due to the different nature of each course, the curriculum implementation sites are also different. For example, practical courses such as piano, dance, vocal music and fine arts 
courses are taught in the professional training room, so that the teaching effect can be guaranteed; and professional core courses such as preschool children's health education, language education, science education, social education, and art education need practical workplaces to exercise students' educational and teaching abilities. Therefore, the university has built a training room that simulates the real situation of kindergartens to enhance students' practical teaching ability.

\section{PRoblems and CAuses of CuRriculum SETtings of PRESCHOOL EDUCATION MAJOR IN X UNIVERSITY}

\section{A. Analysis of Training Objectives}

$\mathrm{X}$ University has a clear training goal for the pre-school education major of. It has made requirements for students' ideological quality, cultural quality, scientific accomplishment, professionalism and social responsibility, learning ability, practical ability, and innovative awareness. It also requires that students have professional basic knowledge and professional skills in speaking, painting, playing, dancing, singing, and bilingual teaching. At the same time, based on the needs of regional economic and social development in Shaanxi Province, a brief summary of the students' employment orientation is made. In general, the standards for pre-school education students have met the needs of current preschool education market and are professional.

\section{B. Analysis of Training Specifications and Requirements}

The university requires students in terms of knowledge, ability, and quality. Students are required to have basic kindergarten organization and management skills, and have the ability to organize and guide early education activities for 0-3 years old children to meet the demand of kindergartens combining with the current development trend of preschool education. This shows that the university attaches great importance to the professional development of preschool education professionals.

\section{Analysis of the Curriculum Structure}

Professional courses include general education courses, professional basic courses, professional core courses, professional limited selection courses and professional optional courses. There is also concentrated practical teaching (professional traineeships and internships). The course structure is complete, the system is perfect, and the emphasis is placed on practical teaching link, students' professional ability can be improved through professional internships and internships.

\section{Analysis of Course Content}

Through the analysis of the course content of the university, it is found that the university does not set up basic courses in education (education, general psychology, human anatomy and physiology), and the basic courses in education are included in three core courses preschool hygiene, preschool education, and preschool psychology. This course content is based on the actual situation of the $X$ University. $X$ University is a private university in Shaanxi Province. It was identified as one of the first applied transformation pilot universities in 2014. The goal of the university is to train applied technology talents. Therefore, the university pays more attention to practical teaching and focuses on cultivating students' practical teaching ability. So the basic courses in education are included in the professional core courses to reflect the importance of practical teaching. Professional limited selection courses and professional optional courses are classified to modular courses and extended courses. This idea is novel. Students can choose their own curriculum system according to their ability and interests, improve their professionalism, expand their employment channels and meet the market demand for preschool education professionals.

\section{E. Analysis of Curriculum Implementation}

In the implementation of the curriculum, each course has attached importance to practical teaching. Based on the differences in the content and nature of the various courses, combined with the current needs of preschool education institutions for talents, the theory and practice hours are reasonably assigned. X University has established a series of preschool education training rooms based on the curriculum's requirements for implementation venues. There are infant activity simulation rooms, preschool art laboratories, preschool science laboratories, infant and child health rooms, and professional training rooms such as art studios, piano rooms, and vocal music classrooms. These can ensure the effectiveness of the curriculum implementation and promote the improvement of students' practical teaching ability.

\section{EXPLORATION OF PRESCHOOL EDUCATION CURRICULUM MODELS FOR CULTIVATING APPLIED TECHNICAL TALENTS IN THE PERSPECTIVE OF PROFESSIONALISM}

Professionalization is the path that must be chosen by teachers to develop. It is the pre-job training that people must have in order to engage in a profession. There are five constituent elements of professionalism. They are the complete knowledge system, professional judgment standards, professional ethics and creeds, social recognition, and professional culture. For the preschool education major, professional theoretical knowledge forms the systematic knowledge system; teachers' professional ethics form the society's judgment standards for preschool education; child care, love, carefulness, and patience are the occupation creeds that preschool teachers should possess; more and more parents have seen the dedication of preschool teachers and preschool teachers have gained a high degree of social recognition; the professional culture determines the unique cultural model of preschool education. Professionalism mainly includes professional behaviors, professional skills and professional qualities. The occupation of preschool teacher requires teachers to regulate their own educational behaviors in their jobs. They have had professional knowledge and skills before starting their careers. Teachers should uphold the concept of lifelong learning during their entire careers and continuously enhance his professionalism. The professionalization of preschool teachers includes the professionalism and development status. The professionalism of preschool teachers 
is reflected in professional knowledge, professional ability, professional quality and professional behavior; the development status of preschool teachers refers to the teachers' promotion of their professional performance through continuous learning and development. Through the research on the curriculum setting of the $\mathrm{X}$ university preschool education major, combined with the development status of the preschool education under the support of the national policies, this paper attempts to explore the curriculum system for the cultivation of applied technology talents in the professional perspective.

\section{A. Diversification of Career Training Goals}

Through the analysis of the training objectives of the $\mathrm{X}$ university preschool education major, it is found that the university pays attention to the diversified development of students. In addition to requiring students to master the basic knowledge and theory of preschool child care and education, it also requires students to master the basic knowledge of bilingual education (English) for preschool children; have the ability to manage kindergartens, know relevant knowledge of early childhood education, have the ability to organize and guide basic early childhood education activities for children aged 0-3 years. The vocational training objectives of $X$ University are diversified. The university's aim is to train highly qualified application-oriented specialists who can engage in teaching, management, and services in kindergartens and other preschool education institutions after graduation.

\section{B. The Scientific Content of Vocational Courses}

The X University was identified as one of the first batch of application-oriented transition pilot universities in 2014. The school's goal is to develop applied technology talents who will adapt to the current regional economy. X University has made professional curriculum content based on its actual conditions. The basic courses that are difficult to understand are integrated into the three major professional core courses, and the proportion of practical teaching in classroom teaching is continuously increased. Professional limited selection courses and professional elective courses are classified into modular courses and extended courses, covering all current preschool education professional skills. Students can freely choose courses according to their own abilities and interests, improve their professionalism and expand their employment channels, and better meet the professional needs of the market for preschool education professionals.

\section{Standardization of Curriculum Implementation}

Due to the special nature of preschool education, practical teaching needs to be emphasized. Schools should rationally allocate theoretical and practical hours based on the different content and nature of each course, combined with the current needs of preschool education institutions for talents. In the teaching process, teachers should pay attention to improving students' practical ability and give students the opportunity to display their own practical teaching ability. Teachers should conduct practical teaching in the infant activity simulation laboratory, preschool art laboratory, preschool science laboratory, infant and child health room, and professional training rooms such as art studios, piano rooms and vocal classrooms to standardize the implementation of the curriculum, guarantee the effectiveness of teaching, and realize the curriculum setting of preschool education major from the perspective of professionalism.

$X$ university maintains good relationships with early childhood education institutions and employers such as kindergartens. It always pays attention to the actual needs of employers, combines with the latest national policies and regulations, continuously standardizes the implementation of the curriculum and further revises and optimizes the preschool education curriculum system.

\section{CONCLUSION}

The preschool education major of colleges and universities is used as a special major for training preschool education personnel. The scientificity and rationality of its curriculum are directly related to the professionalization level of preschool education personnel. Through a detailed study of the preschool education curriculum of the $\mathrm{X}$ university, it is found that the university has adjusted the structure of the curriculum combining with its own training objectives and talent orientation, increased the practical hours, combined the practical skill courses with theory courses, optimized curriculum system according to the current demands of preschool education market, adjusted the curriculum structure in accordance with the relevant policies of the national government. The curriculum of $\mathrm{X}$ University is basically in line with the requirements of professionalism. It has its own unique curriculum model and a complete curriculum system that is worthy of reference by other local colleges of applied technology.

\section{REFERENCES}

[1] Dai Jiaojiao. Research on Curriculum Settings of Pre-school Education in Higher Vocational Colleges_-Taking L Professional Technology Institute's Training Plan as the Text[D]. Master thesis of Shaanxi Normal University, 2012 戴娇娇.高等职业院校学前教育专业课程设 置研究——以 $\mathrm{L}$ 职业技术学院培养计划为文本[D].陕西师范大学硕 士学位论文,2012

[2] Bu Tengteng. Research on Preschool Education Curriculum: Taking YC Kindergarten Teachers College as an Example[D]. Master Thesis of Soochow University, 2016 步滕滕.学前教育专业课程设置研究—— 以 YC 幼儿高等师范学校为例[D].苏州大学硕士学位论文,2016

[3] Wang Xiaocheng, Zhang Peiping, Ming Tinghua. Research and Practice of Preschool Education Curriculum in Higher Vocational Colleges[J]. Reform and Opening, 2013 王晓成,张佩萍,明廷华.高职院校学前教育 专业课程设置的研究与实践 [J].改革与开放, 2013

[4] Wang Yang. Practical Research on Teachers' Education Curriculum System From the Professional Perspective [J]. Teachers' Development, 2016. 王杨.基于职业化视阈的教师教育课程体系实践研究[J].教师 发展, 2016 